Assiut Scientific Nursing Journal

http://asnj.journals.ekb.eg

http://www.arabimpactfactor.com

\title{
Entrepreneurship Orientation Program and Its Effect on the Entrepreneurial Intention of Future Nurses
}

\author{
Hind Ismail Ali', Samah Mohamed Abd Allah² \& Wafaa Abd El Azeem Al-hosany ${ }^{3}$. \\ 1. Assistant Lecturer, Faculty of Nursing, Sohag University, Egypt. \\ 2. Nursing Administration Professor, Faculty of Nursing, Assuit University, Egypt. \\ 3. Nursing Administration Professor, Faculty of Nursing, Suez Canal University, Egypt.
}

\begin{abstract}
Background: Nurses practitioners are so multidimensional, flexible, creative, and organized that developing and operating a business is a natural fit for many. Combine all this with a creative idea to solve a problem or fit a particular niche, and can got some valuable components to starting a small business. Aim: This study aimed to assess the effect of entrepreneurship orientation program on entrepreneurial intention among future nurses. Subjects and Methods: Quasi-experimental research design was adopted to conduct this study. The study was conducted at Suez Canal University Hospitals. The study participants were (76) nursing interns and (37) newly graduate baccalaureates nurses during the academic year 2018-2019. Tools: Entrepreneurial Intention Questionnaire was used for data collection. Results: Based on the participant's responses, the results revealed that there was a significance $\left(\mathrm{P}=0.000^{*}\right)$ improvement from the pretest to the post to the follow-up. Conclusion: The highest percentage of participants had the intention to start their own private practice. This meant that the entrepreneurship orientation program affects the entrepreneurship intention positively. Recommendations: The findings provided valuable insight for higher education institutes to design their curricular in such a way that further the self- efficacy of entrepreneurial actions and positive attitude on entrepreneurship.
\end{abstract}

\section{Keywords: Entrepreneurship, Entrepreneurship Intention, Entrepreneurship Training, Entrepreneurship Program \& Nurses Practitioners.}

\section{Introduction}

One of the missions of the 21 st century University is therefore to encourage the social and economic development of its surroundings through venture creation training and entrepreneurship development (OECD, 2016).Entrepreneurs are considered the backbone of economies as they come up with innovative business ideas which ultimately contribute to the social and economic growth (Israr \& Saleem, 2018). Egyptian society's perception of entrepreneurship is particularly high and continues to grow. Global Entrepreneurship Monitor (GEM) Egypt National Report indicated that more than 73 percent of Egyptians think entrepreneurship is a good career choice. While more than 30 percent of Egyptians shy away from starting a new business due to fear of failure, lack of support and insufficient business skills (Kelley,Singer, \& Herrington, 2016).

Entrepreneurship offers a career option for nurses seeking autonomy in their practice. Nurse entrepreneurs face some distinct issues as they endeavor to offer a range of specialist nursing services from within a business structure. Nursing entrepreneurship provides nurses with selfemployment opportunities which allow them to pursue their personal vision and passion to improve health outcomes using innovative approaches (Wilson, Whitaker, \& Whitford, 2012). Nurse entrepreneurs fill the gaps in the current health care delivery system by supporting the development of targeted products and services, enhanced technology, software, and safety systems. This development provides the health system with an opportunity to address needs within the health system by utilizing the services of private nurse consultants and practitioners (Royal College of Nursing Australia, 2015).

Nursing practice is continually changing with development in medical science, policy directives and movements in priorities in health care and advances emanating from nursing and medical research. Entrepreneurial education is often lacking for nurse practitioners which can impact their ability to successfully run nurse practitioner owned practices. Nurse practitioners lead busy lives and often learn important business skills as they navigate the business start-up process for their practices. There is a need for entrepreneurial nurses within the health services to maintain and enhance the quality of care. Many nurse practitioners go through their masters and doctoral educations without any business skills coursework (Elango, 2017). For those hoping to start their own businesses this can leave the nurse feeling unprepared for the challenges of starting one's own practice whether a new primary care practice or a homevisiting service. 


\section{Significance and aim of the study}

Changes in nursing and health care have created new opportunities and made a greater diversity in nurses` roles and significant advances in nursing knowledge and education (Khan, 2013). As a number of nurses who took the option to develop private practice was increased from 1970 to 2013, the experiences of and influences on nurses currently in private practice might be a useful guide to the pitfalls and difficulties which might be encountered. Entrepreneurship provides an avenue that drives innovation and creates employments that are essential for economic transformation and advancement (Hathaway \& Litan, 2014).

Nursing Entrepreneurship presents an opportunity to explore nursing's professional potential in nursing practice and increase recognition of the value of nursing services. In this context, there is a first Egyptian trial in nursing entrepreneurship which provides high qualified nursing services at homes under the government observation. Also Egyptian government support entrepreneurship through an Egyptian Entrepreneurship association- called Technology innovation and entrepreneurship center TIEC- which provide training and financial support for private practice trials.

Therefor the aim of the current study was to assess the effect of entrepreneurship orientation program on entrepreneurial intention among future nurses

Research hypothesis

The investigator tested the study hypothesis which was "The entrepreneurship orientation program affects entrepreneurial intention positively".

\section{Subjects \& Methods \\ Technical design \\ Research design}

Quasi-experimental research design was adopted to conduct this study. The investigator adopted Pretestposttest research design to achieve the aim of the study. Data collected both (before-after) and followup the intervention; appropriate for measuring change; could determine differences within a group.

\section{Setting}

The study was conducted at Suez Canal University Hospital (Educational Hospital). Suez Canal University Hospital was where the nursing interns training were occurred. In addition, this hospital had the large proportion of graduates of the Nursing Faculty.

\section{Research participants}

The study participants were all the nursing interns and newly graduated worked at Suez Canal University Hospital who were about 113 participants at all phases of the field work as the following:
A. There were 37 newly graduate nurses from Faculty of Nursing during the first two years of recruitment at Suez Canal University hospital during the data collection period.

B. There were 76 nursing interns at Suez Canal University Hospitals (Educational Hospital) during the academic year 2018-2019.

\section{Study tools}

To achieve the purpose of the study, the investigator used a self-administered questionnaire. The questionnaire consisted of three sections:

Section (1): Personal Characteristics data sheet: This section developed by the investigator which included data about participants like; age, gender, family entrepreneurial background and residence, and marital status.

Section (2): Entrepreneurial Intention Questionnaire: This section was developed by Orman (2009) with Cronbach's alpha value is 0.86 .This section reflected the participants desire to become an entrepreneur and consisted of six items. This instrument was scored through 5- points Likert scale, with (1) for strongly disagree, (2) disagree, (3) to some extent, (4) agree and (5) for strongly agree.

Scoring: The total score was equal (30) and classified as: From $85 \%$ to100 \% indicated that participants` entrepreneurial intention was high level; from $60 \%$ to $84 \%$ indicated that participants` entrepreneurial intention was moderate level, less than $60 \%$ indicated that participants`entrepreneurial intention was low level..

Section (3): Entrepreneurial knowledge test: this test was developed by the researcher at the preparatory phase after finishing the program preparation. It aimed to assess participant's knowledge regarding the entrepreneurship before, immediately after and after six month of the program. The test was composed of 10 multi-choices questions about the entrepreneurship such as (Who is in need of a Nurse Entrepreneur: a.Community; b. Individuals; c. Associations; d. All of the above). The scoring system of the knowledge test was calculated as: A correct answer was scored 1 and incorrect answer was scored zero. The cutoff point for satisfactory knowledge was set at $60 \%$ of the total score.

\section{Pilot study}

A pilot study was carried out on (10\%) of the study sample $(n=12)$ prior to the mass distribution of the questionnaire. Cases involved in the pilot study will be included to the main sample. The purpose of the pilot study was to identify logistical problems regarding ease of access and format that could occur during the study and might adversely affect data quantity and quality. The Statistical Package for the Social Sciences (SPSS, version 22) was used for the data analysis. The pilot survey results highlighted that 
there was no need for paraphrasing or modification of any item.

\section{Administrative design}

Official approval was obtained from hospital manager of the Suez Canal University Hospital and the Dean of Faculty of Nursing at Suez Canal University

\section{Operational design}

\section{a) Ethical consideration}

The study followed common ethical principles in clinical research. A primary approval to conduct the proposed study was obtained from the research ethical committee, Faculty of Nursing, Suez Canal University. As well as all Official approvals was obtained. Participation in the study was voluntary and based on their agreement to give informed consent, the ethical issue considerations include explaining the purpose and nature of the study, stating the possibility to withdraw at any time without an adverse impact on their work, confidentiality of the collected data and that participation is with no risk.

\section{b) Procedure}

The investigator developed the Entrepreneurship Orientation program after reviewing the available related literatures about entrepreneurship and nursing entrepreneurship. At this phase also, the investigator contacted with the experts panel to test the face validity of the used tools and modifications were made according to experts` opinions. Face validity was established by five experts in nursing administration field; one professor of nursing administration at Faculty of Nursing, Cairo University, one professor of nursing administration at Faculty of Nursing, Assuit University and one assistant professor of nursing administration at Faculty of Nursing, Sohag University, one professor of Psychology from Sohag university and a senior incubator specialist at entrepreneurship field at Technology Innovation \& Entrepreneurship Center (TIEC).

Data collection procedure was conducted over twelve months (from October 2018 to October 2019) at their subjects` work place. Once the official permission was granted to proceed with the study, the investigator initiated data collection process. The study was accomplished through five phases:

Preparatory Phase: This phase included determining the program strategy time, number of sessions, teaching methods and media used. In addition, the teaching place and program facilities were checked for appropriateness. Numbers of sessions were six sessions; one hour per session; for each group. The participants were divided into four groups based on availability of participant for attendance and the arrangement of nursing director. The investigator developed the Entrepreneurship Orientation program after reviewing the available related literatures about entrepreneurship and nursing entrepreneurship.
At this phase also, the investigator contacted with the experts panel to test the face validity of the used tools and modifications were made according to experts` opinions. Face validity was established by five experts in nursing administration field; one professor of nursing administration at Faculty of Nursing, Cairo University, one professor of nursing administration at Faculty of Nursing, Assuit University and one assistant professor of nursing administration at Faculty of Nursing, Sohag University, one professor of measurement and evaluation, Faculty of Education from Sohag University and a senior incubator specialist at entrepreneurship field at Technology Innovation \& Entrepreneurship Center (TIEC).

Pre-test Phase: The investigator assessed the perceived entrepreneurial intention of the study participants before starting of entrepreneurial orientation program. In addition, the Entrepreneurial knowledge test was conducted at this phase. Pretest phase was conducted for each group. This Pre-test occurred at the same place of training immediately before starting the program

Action Phase: The investigator applied the program over a period of four months from January 2019 to the end of April 2019. The program was held four times, one for each group. The program was conducted at the Suez Canal Hospital training hall. The investigator could hold the program for about 25-30 participants every time. The aim of Entrepreneurship Orientation program was to increase participants` knowledge about entrepreneurship and encourage them to be job creators rather than job seekers.

To achieve the aim of the program and each one of the specific objectives, the program included items as history of entrepreneurship, concept of entrepreneurship, nursing entrepreneurship, importance of nursing entrepreneurship, obstacles and opportunities of nursing entrepreneurship, who is the nurse entrepreneur (definition- qualifications- skills), examples on international nurse entrepreneurs, steps of entrepreneurship process, the motivators to start a private practice (psychological- structural), ideation process, national example for nurse entrepreneurs and referral entrepreneurship associations.

Posttest phase: The investigator reassessed the entrepreneurial intentions immediately after the entrepreneurial orientation program. The Entrepreneurial knowledge test was reassessed at this phase.

Follow up Phase: After six months, the investigator contacted with the participants to assess the perceived entrepreneurial intention and Entrepreneurial knowledge test. The follow-up phase started at June 2019 with the first group who received the program was at January 2019. This phase was finished at October 2019 with the last group who received the 
program at April 2019. The investigator contacted with them at their work place.

\section{Statistical design}

Upon completion of data collection, the data were scored, tabulated, and analyzed through data entry and analysis by computer using the "Statistical Package for Social Science" (SPSS) version 20.
Continuous data was expressed as frequency, percentage; mean and SD. discrete data was expressed as frequency and percentage. Comparison between variables was done using ANOVA test and Chi-square. The $\mathrm{p}$ value $>0.05$ indicated nonsignificant result while, the $\mathrm{p}$ value $<0.05$ was significant and the $\mathrm{p}$ value $\leq 0.01$ was highly significant.

\section{Results}

Table (1): Percentage Distribution of the study participants`Socio- demographic data (N=113).

\begin{tabular}{|c|c|c|c|}
\hline \multirow{2}{*}{ Demographic Items } & \multirow{2}{*}{ Variable } & \multicolumn{2}{|c|}{ Study sample $N=250$} \\
\hline & & No. & $\%$ \\
\hline \multirow[t]{2}{*}{$\overline{\text { Gender }}$} & Male & 22 & 19.5 \\
\hline & Female & 91 & 80.5 \\
\hline Age & \multicolumn{3}{|c|}{$\begin{array}{c}\text { Mean: } \mathbf{2 3 . 8 5} \\
\text { SD: } 1.951\end{array}$} \\
\hline \multirow[t]{2}{*}{ Family background } & Yes & 51 & 45.1 \\
\hline & No & 62 & 54.9 \\
\hline \multirow[t]{2}{*}{ Residence } & Rural & 73 & 64.6 \\
\hline & Urban & 40 & 35.4 \\
\hline \multirow[t]{4}{*}{ Marital status } & Single & 74 & 65.5 \\
\hline & Married & 38 & 33.6 \\
\hline & Divorced & 1 & 0.9 \\
\hline & Widow & 0 & 0 \\
\hline
\end{tabular}

\section{Distribution of Study participants}

Wurse Intents

2nd year of recruitrient

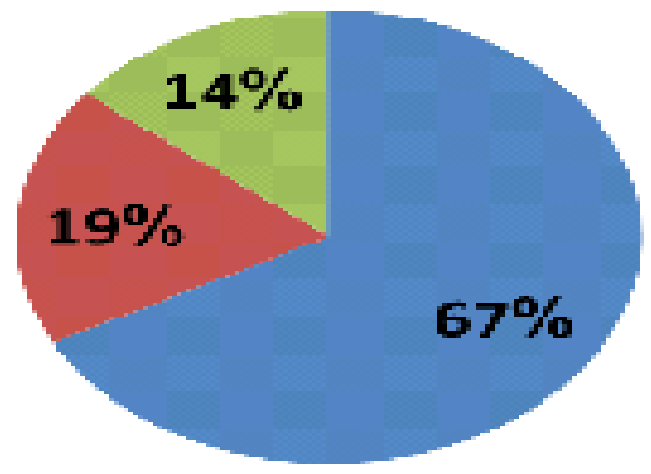

Figure (1): Percentage distribution of the study participants according their job status. $(\mathrm{N}=113)$. 
Table (2) Percentage distribution of study participants`responses to entrepreneurial intention questionnaire from pre, post and follow-up program (N=113).

\begin{tabular}{|l|c|c|c|c|c|c|c|c|c|c|c|c|c|c|c|}
\hline \multicolumn{1}{|c|}{ Items } & \multicolumn{5}{c|}{$\begin{array}{c}\text { Preprogram } \\
\text { (Percentage \%) }\end{array}$} & \multicolumn{5}{c|}{$\begin{array}{c}\text { Post program } \\
\text { (Percentage \%) }\end{array}$} & \multicolumn{5}{c|}{$\begin{array}{c}\text { Follow-up program } \\
\text { (Percentage \%) }\end{array}$} \\
\hline & SA & A & T & D & SD & SA & A & T & D & SD & SA & A & T & D & SD \\
\hline $\begin{array}{l}\text { I am ready to do } \\
\text { anything to be an } \\
\text { entrepreneur }\end{array}$ & 5.3 & 12.7 & 48.1 & 32.1 & 1.8 & 46 & 38.1 & 11.5 & 4.4 & 0.0 & 32.7 & 43.2 & 22.1 & 1.8 & 0 \\
\hline $\begin{array}{l}\text { My professional } \\
\text { goal is becoming } \\
\text { an entrepreneur }\end{array}$ & 2.7 & 8.1 & 46.3 & 43 & 0.0 & 33.6 & 41.6 & 22.1 & 2.7 & 0.0 & 37.2 & 41.6 & 19.5 & 1.8 & 0 \\
\hline $\begin{array}{l}\text { I will make every } \\
\text { effort to start and } \\
\text { run my own private } \\
\text { practice }\end{array}$ & 1.8 & 5.7 & 41.6 & 41 & 10 & 32.7 & 44.2 & 19.5 & 3.5 & 0.0 & 39.8 & 38.9 & 20.4 & 0.9 & 0 \\
\hline $\begin{array}{l}\text { I am determined to } \\
\text { create a private } \\
\text { practice in the } \\
\text { future. }\end{array}$ & 0.9 & 13 & 52 & 23 & 10.9 & 31 & 45.1 & 22.1 & 1.8 & 0.0 & 35.4 & 37.2 & 27.2 & 0 & 0 \\
\hline $\begin{array}{l}\text { I have seriously } \\
\text { though in starting a } \\
\text { private practice. }\end{array}$ & 0.9 & 13 & 52 & 23 & 10.9 & 23.9 & 45.1 & 26.5 & 4.4 & 0.0 & 35.4 & 38.1 & 24.8 & 1.8 & 0 \\
\hline $\begin{array}{l}\text { I have got the } \\
\text { intention to start a } \\
\text { private practice } \\
\text { someday. }\end{array}$ & 0.9 & 8.1 & 46.8 & 34.1 & 10 & 37.2 & 43.3 & 17.9 & 2.7 & 0.0 & 42 & 33.1 & 19.6 & 4.4 & 0 \\
\hline
\end{tabular}

SA=strongly agree $\quad A=$ agree $\quad T=$ to some extent $\quad D=$ disagree $\quad S D=$ strongly disagree

Table (3) Comparison between study participants`entrepreneurial intention pre-post and follow up the program: $(\mathrm{N}=113)$

\begin{tabular}{|l|c|c|c|c|c|c|c|}
\hline $\begin{array}{l}\text { Entrepreneuri } \\
\text { al Intention }\end{array}$ & Pre-test & Post-test & Follow-up & P-value $^{1}$ & P-value $^{\mathbf{2}}$ & P-value $^{\mathbf{3}}$ & P-value $^{-}$ \\
\cline { 2 - 5 } & & & & & & & \\
Mean \pm SD & $19.49 \pm 3.55$ & $24.74 \pm 3.29$ & $24.16 \pm 3.84$ & $0.000^{*}$ & $0.004^{*}$ & $0.013^{*}$ & \multirow{2}{*}{$.000^{*}$} \\
\hline Range & $9-25$ & $15-30$ & $13-30$ & & & & \\
\hline
\end{tabular}

1: Comparison between Pre-test and Post-test.

2: Comparison between Pre-test and Follow-up.

3: Comparison between Post-test and Follow-up

Table (4) Percentage distribution of participants` level of entrepreneurial intention at pre-post and follow-up the program $(\mathrm{N}=113)$

\begin{tabular}{|c|c|c|c|c|c|c|c|c|c|}
\hline Item & \multicolumn{3}{|c|}{$\begin{array}{c}\text { Level of intention (pre- } \\
\text { program) }\end{array}$} & \multicolumn{3}{|c|}{$\begin{array}{c}\text { Level of intention (post- } \\
\text { program) }\end{array}$} & \multicolumn{3}{|c|}{$\begin{array}{c}\text { Level of intention (follow-up } \\
\text { program) }\end{array}$} \\
\hline \multirow[b]{2}{*}{$\begin{array}{l}\text { Entrepreneuri } \\
\text { al intention }\end{array}$} & Low $\%$ & Moderate $\%$ & High $\%$ & Low $\%$ & Moderate $\%$ & High $\%$ & Low \% & Moderate $\%$ & High $\%$ \\
\hline & $\begin{array}{c}68 \\
60.18 \%\end{array}$ & $\begin{array}{c}41 \\
36.28 \%\end{array}$ & $\begin{array}{c}4 \\
3.54 \%\end{array}$ & $\begin{array}{c}2 \\
1.77 \%\end{array}$ & $\begin{array}{c}40 \\
35.40 \%\end{array}$ & $\begin{array}{c}71 \\
62.83 \%\end{array}$ & $\begin{array}{c}11 \\
9.73 \%\end{array}$ & $\begin{array}{c}52 \\
46.02 \%\end{array}$ & $\begin{array}{c}50 \\
44.25 \%\end{array}$ \\
\hline
\end{tabular}


Table (5): Comparison between participants' socio-demographic characteristics on their entrepreneurial intention levels based on their sum mean score of pre-post and follow-up program $(N=113)$

\begin{tabular}{|c|c|c|c|c|c|c|}
\hline \multirow{2}{*}{ Items } & & Low & Moderate & High & \multirow{2}{*}{$\mathbf{t}$} & \multirow{2}{*}{ p } \\
\hline & & No. $(\%)$ & No. (\%) & No. $(\%)$ & & \\
\hline \multirow[t]{2}{*}{ Sex } & Male & $1(4.48 \%)$ & $8(36.38 \%)$ & $13(59.13 \%)$ & \multirow{2}{*}{0.521} & \multirow{2}{*}{0.247} \\
\hline & Female & $4(4.40 \%)$ & $49(53.84 \%)$ & $38(41.76 \%)$ & & \\
\hline \multirow[t]{2}{*}{ Age } & $22 \mathrm{yrs}-25 \mathrm{yrs}$ & $3(3.49 \%)$ & $42(48.84 \%)$ & $41(47.67 \%)$ & \multirow{2}{*}{1.855} & \multirow{2}{*}{0.004} \\
\hline & $26 y r s-30 y r s$ & $2(7.40 \%)$ & $15(55.56 \%)$ & $10(37.04 \%)$ & & \\
\hline \multirow{2}{*}{$\begin{array}{l}\text { Family back- } \\
\text { ground }\end{array}$} & Yes & $2(3.93 \%)$ & $26(50.98 \%)$ & $23(45.09 \%)$ & \multirow{2}{*}{0.012} & \multirow{2}{*}{0.591} \\
\hline & No & $3(4.84 \%)$ & $31(50 \%)$ & $28(45.16)$ & & \\
\hline \multirow[t]{2}{*}{ Residence } & Rural & $3(4.10 \%)$ & $35(47.95 \%)$ & $35((47.95 \%)$ & \multirow{2}{*}{0.233} & \multirow{2}{*}{0.363} \\
\hline & Urban & $2(5 \%)$ & $22(55 \%)$ & $16(40 \%)$ & & \\
\hline \multirow[t]{3}{*}{ Marital status } & Single & $3(4.06 \%)$ & $33(44.59 \%)$ & $38(51.35 \%)$ & \multirow{3}{*}{1.063} & \multirow{3}{*}{0.051} \\
\hline & Married & $2(5.26 \%)$ & $23(60.53 \%)$ & $13(34.21 \%)$ & & \\
\hline & Divorced & $0(0 \%)$ & $1(100 \%)$ & $0(0 \%)$ & & \\
\hline
\end{tabular}

* The mean difference is significant at $(p<0.05)$ level.

** The mean difference is highly significant at $(p<0.01)$ level

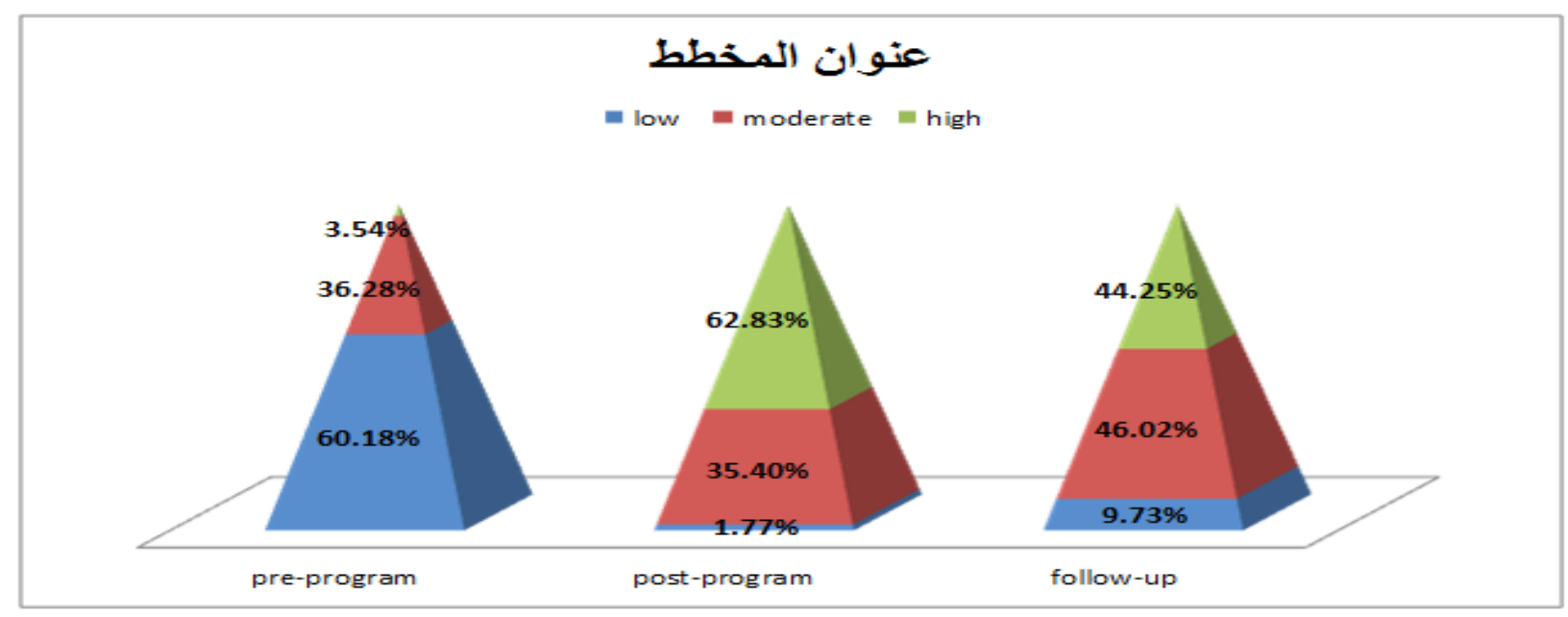

Figure (2) comparison of the study participants` levels of entrepreneurial intention during pre-post and follow-up the program. $(\mathrm{N}=113)$

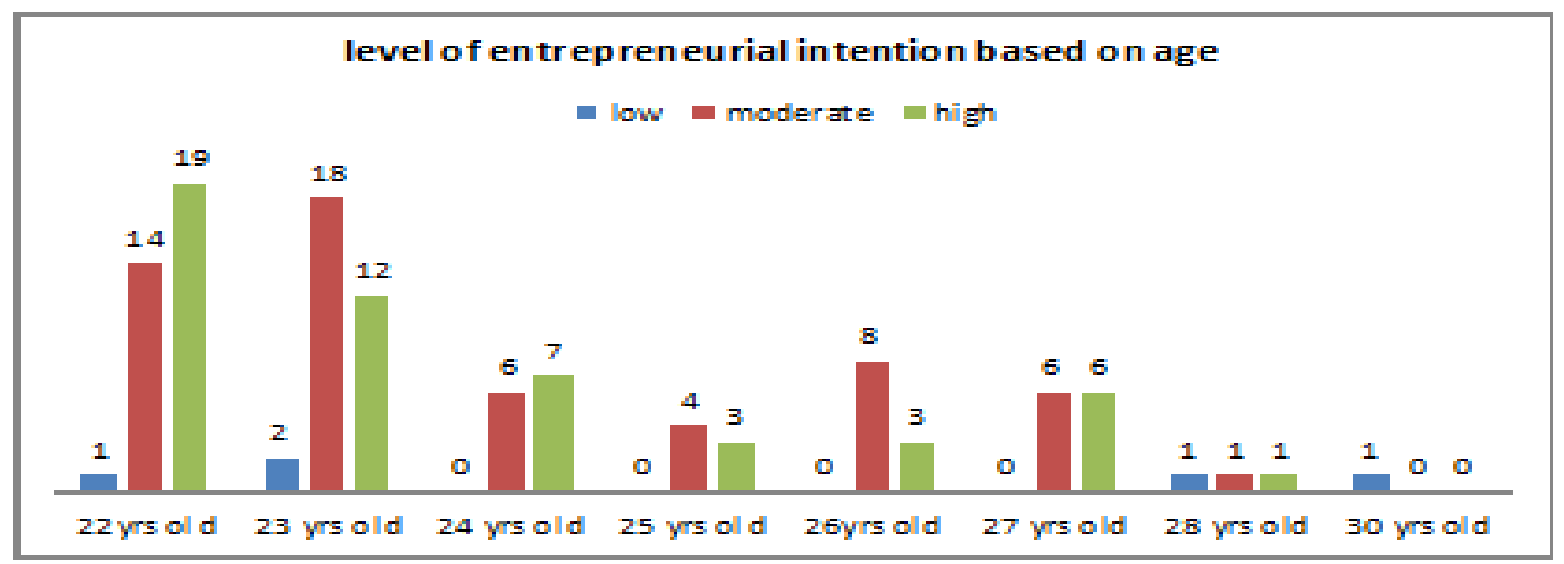

Figure (3) percentage distribution of participants`entrepreneurial intention level based on their ages (N=113). 


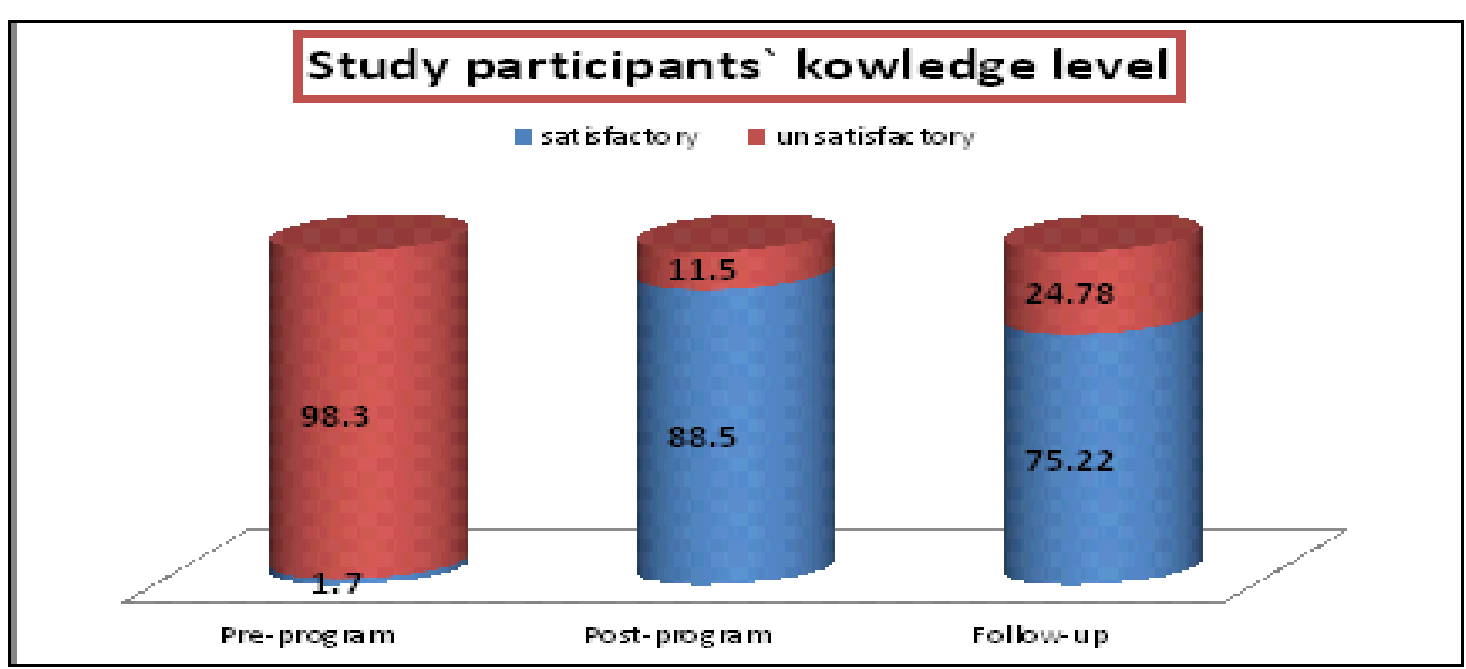

Figure (4): Comparison between study participants` knowledge levels toward entrepreneurship during pre-post and follow-up the program $(\mathrm{N}=113)$.

Table (1): Reveals that, the majority $(\mathrm{n}=91,80.5 \%)$ of the participants were female, the participants age was at mean $23.85 \pm 1.951,(\mathrm{n}=62,54.9 \%)$ had not family background, $(\mathrm{n}=74,65.5 \%)$ of the participants were single, $(n=73,64.6)$ lived at rural areas.

Figure (1) Shows that the study participants divided into three levels where the nursing interns were $67 \%$ of the total participants, $19 \%$ at their first year of recruitment and $14 \%$ at their second year of recruitment.

Table (2): Shows that high percentage of the study participants for the opinion of "to some extent" for the six items of the entrepreneurial intention at preprogram $(48.1 \%, 46.3 \%, 41.6 \%, 52 \%, 52 \%$, and $46.8 \%$ respectively). While majority of the study participants were agreed or strongly agreed for items of the entrepreneurial intention at immediately post program and after six months. The item "I have got the intention to start a private practice someday" had the agreement of the participants by $80.5 \%$ post program and $75.1 \%$ after six months comparing with 9\% preprogram.

Table (3): Illustrates that, participants entrepreneurial intention showed significance $(\mathrm{P}=0.000 *)$ improvement from the pretest $(19.49 \pm 3.55)$ to the post $(24.74 \pm 3.29)$ to the followup $(24.16 \pm 3.84)$.

Table (4): Represents that study participants level of entrepreneurial intention was low $(n=68,60.18 \%)$ pre-program while high $(\mathrm{n}=71,62.83 \%)$ post program. The high percentage $(46.2 \%)$ of participants was at the moderate level of entrepreneurial intention after six months of program.

Figure (2): Shows that the highest percentage of participants had entrepreneurial intention was the post-program immediately, while the highest percentage of them had moderate level of entrepreneurial intention after six months of the program.

Figure (3): Indicates that the youngest participants around age 22 yrs. , 23 yrs. and 24 yrs. had a high level of entrepreneurial intention than other older participants

Table (5): Reveals that there was significant difference between age $(\mathrm{t}=1.855, \mathrm{P}=0.004)$ and marital status $(\mathrm{t}=1.063, \mathrm{P}=0.051)$ and entrepreneurial intention.

Figure (4): Demonstrates that study participants` entrepreneurship knowledge through multiple choice questions at pre-post and follow-up the program where their knowledge level was unsatisfactory at pre-program. While their knowledge level was satisfactory at post-program $(88.5 \%)$ and follow-up $(75.22 \%)$

\section{Discussion}

Entrepreneurship is such a vast and viable area for nurses that it deserves its own separate chapter from the other alternative careers. They often see the voids in the system which prevent patients from receiving appropriate care, or those black holes which can keep an operation from running smoothly. Nurses also have many and varied professional contacts. Combine all this with a creative idea to solve a problem or fit a particular niche, and can got some valuable components to starting a small business.

Findings of the present study revealed the following: Regarding the socio-demographic data of the participants of the current study at all study phases showed that the majority of the study participants were females $(80.5 \%)$ and their ages varied from 22 to 30 years old with the mean age $23.85 \mathrm{~S} \pm 1.951$. More 
than the half of the study participants had no family background toward entrepreneurship. Near to two quarters of the participants were from rural areas. The marital status of the participants mainly were single (65.5\%), was only one divorced participant and the rest was married. About two quarters of the study participants were nursing interns and the rest was newly graduates.

Regarding to the entrepreneurship intention questionnaire, At the pre-program phase, the study participant's answers for the six items mainly directed to "to some extent" and "disagree". The study participants" perceptions were mainly changed immediately post the program and they choose "agree" and "strongly agree" for the most answers. The total level of intention was high at the immediately post- program $(62.83 \%)$ rather than after six months $(44.25 \%)$ of the program.

A study for Mirandaa, Meraa, \& Rubio, (2018) about the determinants of entrepreneurial intention proved that there was insignificant difference $(\mathrm{p}=0.8)$ in entrepreneurship intention related to entrepreneurial training (ET). The result of the present study showed that there was a significant $(\mathrm{P}=0.000 *)$ improvement from the pretest $(19.49 \pm 3.55)$ to the post $(24.74 \pm 3.29)$ to the followup(24.16 \pm 3.84$)$ which was supported by another researchers who emphasized that training for entrepreneurship provides support for entrepreneurs tend to favor the willingness to start a business (Siegel \& Wright, 2015).

Also, Rauch and Helsinki (2015) demonstrate that ET directly affects entrepreneurship intention by allowing access to resources that facilitate the entrepreneur's work and access to the experience of other entrepreneurs thanks to this training. A Malaysian study on graduates also revealed that there was a significance difference $(\mathrm{p}=0.001)$ of entrepreneurial intention related to perceived entrepreneurial educational support (Ambad \& Damit, 2016). That was highlighted the positive effect of entrepreneurship orientation for improving the entrepreneurship intention among young graduates.

Based on the study of Kelley, Singer, \& Herrington, (2016) which proved that the most proximal predictor of the decision to become an entrepreneur is seen in EI, the result of the study showed high level of intention among study participants post the program with high positive response to the statement "My professional goal is becoming an entrepreneur" at immediately post- program (75.2\%), and after six months $(78.8 \%)$. This result was also supported by another researcher study which stated that entrepreneurship education also influences students' career choice (Peterman \& Kennedy, 2013) As similar study has been conducted in Malaysia found that appropriate entrepreneurship education exposure will influence the students to be an entrepreneur (Mohamed et al., 2012).

Altinay et al., (2012) in a study of university hospitality students in the UK found that, family entrepreneurial background positively related to entrepreneurial intention. Despite that, the present study revealed that there was an insignificant $(p=0.591)$ change in entrepreneurial intention related to the entrepreneurial family background of the participants. This result may be due to that the number of the study participants who have no entrepreneurial family background $(54.9 \%)$ is more than the number of who has $(45.1 \%)$. Also this may be related to the level of entrepreneurial intention was near among both group of them. Similarly to the present study, there was another study conducted in Sri-Lanka (2014) which indicated that the majority (145) of the participants has no prior experience of their parents' business, but 87 of them have an entrepreneurial intention (Weerakoon,\& Gunatissa, 2014). Another previous study on Vietnamese postgraduates supported the current study results that participants whose parents were self-employed score higher entrepreneurial intention, but the difference was not statistically significant.

However, there was an insignificant difference $(\mathrm{p}=0$. 247) of entrepreneurial intention related to gender, the highest level of intention $(59.13 \%)$ was for the male participants comparing with moderate level of intention $(53.84 \%)$ to the female participants. This was may be due to the majority of the participants was females so statistically that result in insignificance difference. This result was congruent with a study for Goel, et al., (2015) where $51.4 \%$ of those who had an entrepreneurial intention were male undergraduates and the majority of those who have no entrepreneurial intention (66.2\%) was comprised with female undergraduates.

Another previous study revealed that there was insignificant difference between male and females regarding to entrepreneurial intention, which supported the current study results (Lĩnán\& Fayolle, 2015) In addition, Zhao et al. (2015) supported the present results by concluding that women were less likely than men to desire becoming an entrepreneur. In contrast, some studies showed no meaningful difference between men and women in terms of intentions to start businesses (Kourilsky \& Walstad, 1998, Shay \& Terjensen, 2005, Smith et al., 2016, Chaudhary, 2017).

The present results revealed that there was a significant difference $(p=0.004)$ among age ranges on entrepreneurial intention. The youngest participants were highly intended than others. This finding was consistent with many previous studies which confirm 
that age was negatively associated with entrepreneurial intention (Weber \& Schaper, 2004, Levesque \& Minniti, 2006, Kautonen, 2008, Hatak et al., 2015) This finding was inconsistent with the confirmation from Chaudhary (2017) that there was insufficient statistical evidence to support that age is inversely related to entrepreneurial inclination. People may think more conservatively about their capabilities and visions. As a result, they may become uninterested in taking substantial risks requiring extra time and energy to manage these risks and recover losses. Some earlier studies concluded that older people were more risk-averse than younger ones (Miranda, Chamorro \& Rubio, 2017). Therefore, this result calls for further research on impact of age on entrepreneurial intention.

Marriage can have effects on people's concerns, values and priorities. It is a decision for a way of life. The present study result indicated that there was a significant difference $(\mathrm{p}=0.051)$ of entrepreneurial intention related to marital status where the single participants were highly intended. This might be due to changes responsibilities and decisions especially pertaining to the financial aspects of one's life. Due to risks associated with entrepreneurship e.g. possibility of losing all the savings, a married person may doubt to invest money to risky projects considering the future of his or her family. Single people may feel easier to assume such risks (Saeed, et al., 2016) In contrast to the present study, a previous study in Turkey found that there was insignificant $(p=0.919)$ difference of entrepreneurship intention and marital status (Saral, \& Alpkan, 2019) This may be a result of change in study sample size, cultural perception of participants or the educational preparation.

Individuals can be easily influenced by contextual environments. Geographic location dictates input costs such as rent, labor, and capital, scale of market, and regulations and taxes. Thus, an individual decision to start a new business would vary depending on location (Guerrero\& Urbano, 2014). Despite of the previous opinion and what stated by Baum and Oliver (1992) that in regions with high population density, there are more opportunities to gain effective knowledge and create extensive social networks. The present study findings indicated that there was an insignificant $(p=0.363)$ difference in entrepreneurial intention with residence. The study participants who were from rural area $(47.95 \%)$ were highly intended to start business than others from urban $(40 \%)$. This finding is supported by Yusof \& Jain, (2010) who stated that the availability of resources is not necessarily the key factor to assist entrepreneurs, but the individual's perception of the usefulness and available resources influences individual entrepreneurial intent.

\section{Conclusion \& Recommendations}

Overall, the study concluded that:

About three quarters of study participants were intended to be an entrepreneur. Single young participants had a high level of entrepreneurial intention than other participants as there was a significant difference between level of entrepreneurial intention and participants` marital status and age. Further, the entrepreneurship orientation program affects entrepreneurial intention positively.

This study revealed that entrepreneurship training can motivate young graduates to start their own private practice which had positive effects on the economy and health of the country and nursing profession. These results enrich nursing knowledge with new venture for nurses to frame their own practice and enhancing to the professional practice. This knowledge can help the academicians and nursing managers in the development of new strategies that enhance nursing entrepreneurship.

Based on important findings of the study, the following recommendations were suggested:

- The findings provide valuable insights for nursing mangers and nursing educators to promote entrepreneurship training and provide better support for nursing students to pursue entrepreneurial success.

- Higher education institutes have a vital role to design their curricular in such a way that further the self- efficacy of entrepreneurial actions and positive attitude on entrepreneurship among undergraduates.

- Conduct additional research with more practicing nurses to learn more and what else should to be done to support the nurse entrepreneurs.

\section{Limitation of the study}

The sample of nurses who participate in the study may not accurately reflect all future nurses` perception around the world. Another limitation of this study is that results should be viewed in light of the data having been collected in the health care profession. This may cast some doubts on the suitability of generalization to other professional sectors.

\section{References}

1. Altinay, L., Madanoglu, Melih, D., Roberto, L., Conrad, (2012): The influence of family tradition and psychological traits on entrepreneurial intention. International Journal of Hospitality Management. Vol. 32,No.2, pp.489-499.

https://www.researchgate.net/publication/2515 47760_The_influence_of_family_tradition_an 
d_psychological_traits_on_entrepreneurial_int ention

2. Ambad, S., Damita, D., (2016): Determinants of Entrepreneurial Intention among graduates in Malaysia. fifth international conference on marketing and retailing (5th incomar). Procedia Economics and Finance. Vol. 37; pp. 108-114. Available at: http://creativecommons.org/licenses/by-ncnd/4.0/

3. Baum, J., \& C. Oliver, (1992): Institutional Embeddedness and the Dynamics of Organizational Populations. American Sociological Review, 57, 540-559.

4. Chaudhary, R., (2017): Demographic factors, personality and entrepreneurial inclination: A study among Indian university students. Education+ Training, Vol.59, No.2, pp. 171$187 . \quad$ Available at: https://eric.ed.gov/?id=EJ1124945

5. Elango, (2017): Barriers to nurse entrepreneurship: A study of the process model of entrepreneurship. Journal of The American Academy Of Nurse Practitioners,Vol.19, No.4, pp. 198-204. Available https://www.ncbi.nlm.nih.gov/pubmed/174305 40

6. Goel, R., Goktepe-Hulten, D., \& Ram, R., (2015): Academics' entrepreneurship propensities and gender differences. Journal of Technology Transfer, Vol.40, No.1,pp.161177.

7. Guerrero, M., \& Urbano, D., (2014): Academics' start-up intentions and knowledge filters: An individual perspective of the knowledge spillover theory of entrepreneurship. Small Business Economics, Vol.43, No.1, pp. 57-74. Available at: https://www.jstor.org/stable/43553734?seq=1

8. Hatak, I., Harms, R., Fink, M., (2015): Age, job identification, and entrepreneurial intention. Journal of Managerial Psychology, vol.30, No.1, pp. 38-53.

9. Hathaway, I., \& Litan, R., (2014): Declining business dynamism in the United States: A look at states and metros. Brookings Institution.

10. Israr, M., \& Saleem, M., (2018) Entrepreneurial intentions among university students in Italy.Journal of Global Entrepreneurship Research vol:12, pag.8:20 Available at: https://www.researchgate.net/publication/32653 9971_Entrepreneurial_intentions_among
11. Kautonen, T., (2008): Understanding the older entrepreneur: Comparing third age and prime age entrepreneurs in Finland. International Journal of Business Science and Applied Management, Vol.3, No3,pp. 3-13.

12. Kelley, D., Singer, S., \& Herrington, M., (2016): 2015/2016 Global Report. Global Entrepreneurship Monitor (GEM). Global Entrepreneurship Research Association (GERA).

13. Khan, K., (2013): Empirical analysis of entrepreneurial intentions. A case of Kabul based business students, Afghanistan, International Journal of Information, Business and Management, Vol. 5, No. 1, pp. 184-197 Available at: http://bazekon.icm.edu.pl/bazekon/element/bw meta1.element.ekon-element-000171433050

14. Kourilsky, M., \& Walstad, W., (1998): Entrepreneurship and female youth: Knowledge, attitudes, gender differences, and educational practices. Journal of Business Venturing, Vol.13, No.1, pp. 77-88. Available at:

https://econpapers.repec.org/article/eeejbvent/ v_3a13_3ay_3a1998_3ai_3a1_3ap_3a7788.htm

15. Levesque, M., \& Minniti, M., (2006): The effect of aging on entrepreneurial behavior. Journal of Business Venturing, vol.21, No.2, pp. 177-194.

16. Lĩ̃nán, F., \& Fayolle, A., (2015): A systematic literature review on entrepreneurial intentions.International Entrepreneurship and Management Journal, Vol.11, No.4,pp. 907933. Available at: https://www.researchgate.net/publication/3305 63623_Determinants_of_student_entrepreneur ship_An_assessment_on_higher_education_in stitutions_in_Brazil

17. Miranda, F., Chamorro, A., \& Rubio, S., (2017): Determinants of the intention to create a spin-off in Spanish universities. International Journal of Entrepreneurship and Innovation Management (in press).

18. Mirandaa, F., Meraa, A., \& Rubio, S., (2018): An analysis of the determinants of entrepreneurial intention. European Research on Management and Business Economics vol.23, pp. 113-122. Available at: http://creativecommons.org/licenses/by-nc$\mathrm{nd} / 4.0 /$

19. Mohamed, Z., Rezai, G., Shamsudin, M., \&Mahmud. M., (2012): Enhancing young graduates' intention towards entrepreneurship development in Malaysia. Education+ 
Training, Vol. 54 No. 7, 2012 pp. 605-618. www.emeraldinsight.com/0040-0912.htm

20. OEDC, (2016): Economic Policy Reforms, OEDC publishing at http://www.oecd.org/eco/monetary/.

21. Orman, S., (2009): Factors Affecting Entrepreneurial Intentions: An Application for University Students and University Graduate Employees, (Unpublished Master Dissertation).

22. Peterman, N., \& Kennedy, J., (2013): Enterprise education: Influencing students' perceptions of entrepreneurship. Entrepreneurship Theory and Practice, Vol.28, No.2, pp. 129-144. Available at: https://journals.sagepub.com/doi/full/10.1046/j $.1540-6520.2003 .00035 . \mathrm{x}$

23. Rauch, A., \& Hulsink, W., (2015): Putting entrepreneurship education where theintention to act lies: An investigation into the impact of entrepreneurship educa-tion on entrepreneurial behavior. Academy of Management Learning \& Education,Vol.14, No.2,pp. 187-204. Available at: https://pdfs.semanticscholar.org/e7ac/9e97342 9dd7d3005f6fbbe223795e5866087.pdf

24. Royal College of Nursing, Australia, (2015): Nursing in General Practice: A guide for the general practice team. Available at: https://acn.edu.au/wp-

content/uploads/2017/11/Nursing_in_General_ Practice_C20.pdf

25. Saeed, S., Yousafzai, S., Yani de Soriano, M., \& Muffatto, M., (2015): The role of perceived university support in the formation of students' entrepreneurial intention. Journal of Small Business Management, Vol.53, No.4, pp. 1127-1145. Available at: https://onlinelibrary.wiley.com/doi/full/10.111 $1 /$ jsbm. 12090

26. Saral, H., \& Alpkan, L., (2019): Differences In Entrepreneurial Intention And Characteristics According To Demographics And Other Factors. The European Proceedings of Social \& Behavioural Sciences (EpSBS). Available at: https://dx.doi.org/10.15405/epsbs.2019.01.02. 32

27. Shay, J., \& Terjensen, S., (2005): Entrepreneurial aspirations and intentions of business students: A gendered perspective. In Babson Entrepreneurship Conference, Boston, MA.

28. Siegel, D., \& Wright, M., (2015): Academic entrepreneurship: Time for a rethink? British Journal of Management, Vol.26, No.4, pp.
582-595.

Available

at: https://onlinelibrary.wiley.com/doi/10.1111/14 67-8551.12116

29. Smith, R., Sardeshmukh, S., Combs, G., (2016): Understanding gender, creativity, and entrepreneurial intentions. Education+ Training, Vol.58, No.3, pp. 263-282. Available https://www.emerald.com/insight/publication/i ssn/0040-0912/vol/58/iss/3

30. Weber, P., \& Schaper, M., (2004): Understanding the grey entrepreneur. Journal of enterprising culture, vol.12, No.2, pp.147164.

31. Weerakoon, W., \& Gunatissa, H., (2014): Antecedents of Entrepreneurial Intention. International Journal of Scientific and Research Publications, Vol 4, No.11. Available at: www.ijsrp.org

32. Wilson, A., Whitaker, N., \& Whitford, (2012): Rising to the Challenge of Health Care Reform with Entrepreneurial and Intrapreneurial Nursing Initiatives. Journal of Issues in Nursing. Vol.12, No. 2. Available at: http://ojin.nursingworld.org/MainMenuCatego ries/ANAMarketplace/ANAPeriodicals/OJIN/ TableofContents/Vol-17-2012/No2-May2012/Rising-to-the-Challenge-of-Reform.html

33. Yusof, M., \& Jain, K., (2010): Categories of university-level entrepreneurship: Aliterature survey. International Entrepreneurship and Management Journal, 6(1),81-96.

34. Zhao, H., Seibert, S., Hills, G., (2015): The mediating role of self-efficacy in the development of entrepreneurial intentions. Journal of Applied Psychology, Vol.90, No.6,pp. 1265-1272. . Available at: https://pdfs.semanticscholar.org/2a9c/ef0efb7b 8f7cf4dd9cbef17e015b54c02e30.pdf 